
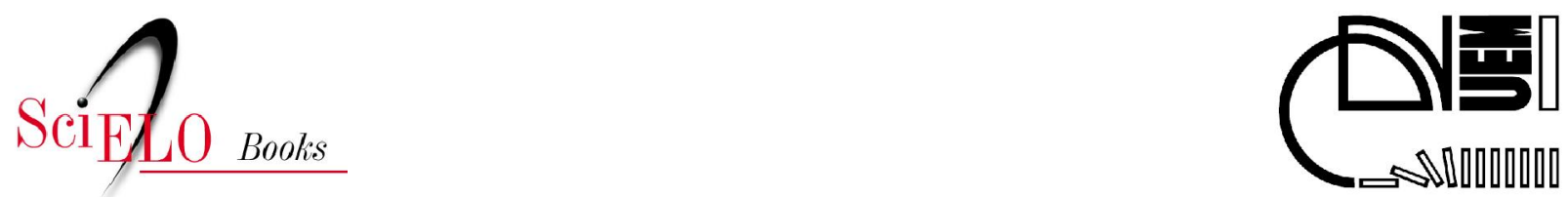

\title{
Prefácio à edição original
}

\author{
Gerd Kohlhepp
}

SciELO Books / SciELO Livros / SciELO Libros

KOHLHEPP, G. Prefácio à edição original. In: SOETHE, PA., org. MARTINESCHEN, D., et al., transl. KOHLHEPP, G. Colonização agrária no Norte do Paraná: processos geoeconômicos e sociogeográficos de desenvolvimento de uma zona subtropical do Brasil sob a influência da plantação de café [online]. Maringá: Eduem, 2014, pp. 25-26. ISBN 978-85-7628-655-4. Available from SciELO Books $<\underline{\text { http://books.scielo.org }>\text {. }}$

\section{(1) (1) (2)}

All the contents of this chapter, except where otherwise noted, is licensed under a Creative Commons Attribution-Non Commercial-ShareAlike 3.0 Unported.

Todo o conteúdo deste capítulo, exceto quando houver ressalva, é publicado sob a licença Creative Commons Atribuição Uso Não Comercial - Partilha nos Mesmos Termos 3.0 Não adaptada.

Todo el contenido de este capítulo, excepto donde se indique lo contrario, está bajo licencia de la licencia Creative Commons Reconocimento-NoComercial-CompartirIgual 3.0 Unported. 
Este livro é o resultado de uma viagem de pesquisas realizada entre maio e novembro de 1970 ao Estado do Paraná, Brasil. A viagem tornou-se possível graças ao generoso patrocínio da DFG Fundação Alemã para a Pesquisa Científica, à qual devo especial agradecimento pela bolsa de estudos para minha habilitação acadêmica, como também à oportuna ajuda de custo para a impressão do meu trabalho.

Contudo, a escolha do Paraná como território de pesquisa de campo deve-se a uma viagem anterior, focada nos problemas específicos do desenvolvimento regional, que, já com o apoio da DFG, pude empreender em 1965 em companhia do meu respeitado Professor, Dr. G. Pfeifer, às regiões Sul, Sudeste e Central do Brasil: a ele aqui expresso meu agradecimento por seu múltiplo apoio, as muitas discussões e o extraordinário interesse pessoal e científico, com que acompanhava e incentivava o curso dos trabalhos.

As breves visitações subsequentes do terreno, realizadas no período que vai de 1965 a 1968, e que contemplavam a investigação comparativa de outro repertório de questões, auspiciaram-me a oportunidade de acompanhar a trajetória do processo de desenvolvimento geo-cultural do Paraná. Essas viagens não apenas proporcionaram a assimilação de importantes conhecimentos sobre o país em si, como também facilitaram o primeiro acesso às fontes da pesquisa, em particular, os acervos estatístico e aerofotogramétrico, estabelecendo também grande número de contatos humanos e profissionais, que muito me auxiliaram durante a interpretação do material, em 1970.

Agradecido, evoco os muitos incentivos e referências do Prof. Dr. Reinhard Maack, de Curitiba, que durante minhas viagens anteriores e na preparação da minha estada enquanto pesquisador introduziume às suas experiências acumuladas durante décadas no Paraná, mas que infelizmente não mais vivenciou o início propriamente dito das atividades ${ }^{3}$.

É oportuno lembrar que a realização das pesquisas foi facilitada pelo interesse, o espírito cooperador e a assessoria de grande número de pessoas físicas, funcionários de autarquias públicas e instituições e organismos privados, na prospecção de informações e materiais em todos os âmbitos da investigação, em particular em Curitiba, São Paulo, no porto de Paranaguá, exportador de café, mas também em Santos, no Rio de Janeiro e Brasília.

A receptividade e postura generosa de agentes de todas as camadas sociais, em grande número de encontros e sindicâncias - fossem proprietários de terra, administradores, arrendatários parciais, trabalhadores rurais e sazonais ambulantes; fosse durante a interpretação de contratos de trabalho e levantamento estatístico em fazendas de todos os portes; fosse ainda em Prefeituras, filiais da Cia. Melhoramentos Norte do Paraná, sedes regionais da Acarpa, da empresa Cotia, ou no convívio com agrônomos e escritórios regionais do Instituto Brasileiro do Café e do Gerca, como também durante o mapeamento do material - todos esses contatos foram, enfim, de enorme valia para a realização da minha pesquisa, motivo pelo qual registro aqui meu reconhecimento do tradicional espírito de colaboração e meu sincero agradecimento à cordial hospitalidade brasileira.

Meu agradecimento especial vai para as famílias H. M. Bresslau e A. von Treuenfels, de Rolândia, que me acolheram em suas residências, onde por algum tempo me foi permitido instalar minha "base operacional".

Infelizmente, o espaço exíguo não permite recordar nominalmente todas as pessoas e repartições que o mereceriam, advirto, porém, que os nomes de meus informantes mais importantes estão registrados ao longo de todos os capítulos do presente trabalho.

Contudo, em nome de tantos aqui não citados, desejo lembrar, agradecido, o Sr. A. W. Nieffeler, o Dr. W. Babkov (CMNP), o Dr. H. Maier e o Eng. Agr. G. Neves Calefti (IBC/Gerca), em Maringá. Em Londrina tive o apoio do srs. V. Frech e K. Schnitzius, além do Dr. I. Meirelles (Faep), e P. C. Rohrbach (DGTC). Em Curitiba auxiliaram-me a sra. Dr. G. Maack e a família Dr. G. Kurowski.

2 Tradução de Frederico Füllgraf.

3 O Prof. Maack faleceu em 26 de agosto de 1969 [N.T.] 
Meu profundo agradecimento é extensivo a todos os colegas e amigos brasileiros, lotados em diversas faculdades de Curitiba e do Rio de Janeiro, em especial aos professores Lysia M. C. Bernardes, Nilo Bernardes, Maria do Carmo Corrêa Galvão, Orlando Valverde, e aos professores e colegas da Fundação Instituto Brasileiro de Geografia, pelo grande número de sugestões e sua valiosa colaboração.

O caráter temporário de minha permanência e o decreto-lei que controla a pesquisa científica de estrangeiros no Brasil, a impossibilidade do acesso às imagens aerofotogramétricas mais recentes, assim como a atitude reservada, ditada pela conjuntura político-econômica, de órgãos governamentais face ao meu pedido de informações detalhadas; os grandes obstáculos, enfim, interpostos à minha tentativa de acesso aos dados estatísticos não foram capazes de refrear decisivamente o curso das pesquisas.

Muito agradecido sinto-me, finalmente, ao Prof. Dr. H. Graul, por ter-me liberado de minhas funções no Instituto Geográfico de Heidelberg, durante minha viagem de pesquisas e a vigência da bolsa de habilitação ao Professorado, como também devo agradecer ao Prof. Fricke pelo interesse e o apoio proporcionado à pesquisa, que no outono de 1972 foi aceita pela Faculdade de Geociências da Universidade de Heidelberg, como Tese de Habilitação.

Aos editores das 'Heidelberger Geographische Arbeiten' [Obras Geográficas de Heidelberg] agradeço pela seleção da minha pesquisa para essa série editorial; agradecimento extensivo aos funcionários da Editora Franz Steiner, por sua assistência durante a edição do texto.

Agradeço também à sra. Maria Solymossy, cartógrafa da unidade de Geografia Cultural do Instituto Geográfico da Universidade de Frankfurt, por seu valioso trabalho de ilustração cartográfica, em especial, a produção dos mapas coloridos.

Dedico a presente publicação à minha esposa, a cujo incansável apoio com digitação, revisão, além da produção cartográfica, deve-se em grande parte a concretização da presente publicação.

Devido à minha mudança de Heidelberg para Frankfurt, infelizmente a produção gráfica sofreu algum atraso. Originalmente concluída no verão de 1972, a pesquisa sofreu atualizações cabíveis, dois anos mais tarde.

Frankfurt, em dezembro de 1974.

Gerd Kohlhepp 